\title{
Membaca Makna Ornamen Pepatraan Meja dan Kursi di Ruang Pengadilan Kerthagosa Klungkung Bali
}

\author{
An-nisaa Kurnia Widianti ${ }^{1}$, Anung Bambang Studyanto ${ }^{2}$ \\ ${ }^{1}$ Program Studi Desain Interior, Universitas Sebelas Maret Surakarta \\ Email : annisaakurnia10@gmail.com \\ ${ }^{2}$ Departemen Desain Interior FSRD, Universitas Sebelas Maret Surakarta \\ Email : masanungbs@gmail.com
}

\begin{abstract}
ABSTRAK
Bali merupakan salah satu pusat seni ukir atau seni pahat yang menghasilkan suatu wujud citra visual yaitu ornamen (ragam hias). Wujud perupaan dari sebuah ornamen merupakan hasil pemikiran tradisi adat budaya (local genius) serta keagamaan yang memiliki unsur keindahan (estetika) dan makna. Ornamen yang akan dibahas dalam penelitian ini adalah pepatraan. Pepatraan sendiri berasal dari kata patran yang artinya daun. Ornamen patra sendiri merupakan hasil stilasi dari bentuk tumbuh-tumbuhan yang disusun berjajar dan berulang sehingga membentuk satu kesatuan. Penulis berusaha mengkaji kembali makna pepatraan (motif tumbuh-tumbuhan) di mana saat ini pengetahuan tentang kekayaan seni tradisional sudah hampir memudar. Pendekatan-pendekatan yang dipergunakan dalam penelitian ini adalah ilmu tafsir (hermeunetik) atas persepsi ornamentik pepatraan pada meja dan kursi di ruang pengadilan Kertha gosa Klungkung Bali. Adanya akulturasi antara budaya China yang mempengaruhi Majapahit di Bali membawa pengaruh sampai kepada sistem pemerintahannya yang terdapat di Kerajaan Klungkung Kertha gosa Bali. Kehadiran sebuah ornamen tidak semata sebagai pengisi ruang kosong dan tanpa arti, terlebih untuk karya peninggalan masa lalu seperti meja dan kursi di Kertha gosa Bali.
\end{abstract}

Kata Kunci : ornamen pepatraan, Kerthagosa, Bali

\section{PENDAHULUAN}

Dalam sejarah perkembangan Seni dunia, Bali merupakan salah satu daerah di Indonesia yang kaya akan kebudayaan, bahkan sampai dengan saat ini masyarakat lokal Bali masih memegang teguh kebudayaan warisan leluhur mereka. Di bidang Seni Ukir, Bali mampu memikat mata dunia, salah satunya dengan karya seni ukir dalam bentuk ragam hias atau ornamen. Sebuah ornamen, tidak hanya membuat suatu perupaan citra visual lebih dekoratif melainkan lebih bermakna. Pada umunya kehadiran ornamen suatu produk benda yang dihasilkan terkesan lebih bernilai dan estetis. Dengan begitu, penghargaan terhadap objek tersebut menjadi lebih meningkat dalam hal material berbasis tradisi budaya, diiringi dengan wacana budaya masyarakat Bali yang masih menjunjung tinggi struktur sosial.

Ornamen yang digunakan di daerah Bali dibubuhkan dalam berbagai objek, seperti dalam suatu ruang interior untuk fungsi dekoratif, arsitektur, pernak-pernik, serta furnitur. Tidak jarang ornamen yang terdapat pada objek tersebut memiliki nilai simbolik atau makna tertentu sesuai dengan tujuan dan konsep pembuatnya, sehingga dapat meningkatkan status sosial pemiliknya. Dengan demikian, suatu ornamen tidak dapat dipisahkan dari faktor latar belakang sosial budaya, ajaran agama yang bersangkutan, sehingga pada umumnya ornamen memiliki ciri khas tersendiri dan jenis yang beraneka ragam sebagai buah hasil pemikiran dari sistem budaya sosial yang menjadi satu acuan dasar.

Secara fungsional, suatu ornamen juga harus mampu membentuk suatu elemen identitas. Walaupun diolah sedemikian rupa untuk memperlihatkan keindahannya, namun pada hakekatnya benda-benda alam yang dijadikan bentuk-bentuk hiasan masih menampakkan identitasnya. Estetika, etika dan logika merupakan dasar-dasar pertimbangan dalam mencari, mengolah dan menempatkan ragam hias yang mengambil tiga kehidupan di bumi, manusia, binatang (fauna) dan tumbuh-tumbuhan (flora) (Arsitektur Tradisional Daerah Bali, 1981/1982). 
Ragam hias tradisional Bali umumnya merupakan stilasi bentuk-bentuk benda alam yang semata tidak hanya untuk keindahan, melainkan mampu membawa pengaruh yang baik kepada penggunanya. Hal ini menjadi menarik ketika penulis terinspirasi dari sebuah ruang pengadilan kerta $^{1}$ gosa $^{2}$ di Bali, dimana pada meja dan kursi tersebut terdapat banyak ornamen pepatraan ${ }^{3}$. Dalam pepatran sendiri masih banyak dijumpai berbagai jenis-jenisnya, yaitu lung dan sulur.

Kehadiran sebuah ornamen tidak semata sebagai pengisi bagian kosong dan tanpa arti, lebihlebih karya-karya ornamen pada masa lalu yang diungkapkan oleh Aryo Sunaryo (2009). Dst . Bermacam bentuk ornamen sesungguhnya memiliki beberapa fungsi, yakni (1) fungsi murni estetis, (2) fungsi simbolis, dan (3) fungsi teknis konstruktif (Aryo Sunaryo, 2009). Dst.

Fungsi simbolis ornamen pada umumnya dijumpai pada produk-produk benda upacara atau benda-benda pusaka dan bersifat keagamaan atau kepercayaan, menyertai nilai estetisnya (Aryo Sunaryo, 2009). Tetapi dalam perkembangannya kemudian, segi fungsi simbolis ini semakin kehilangan makna. Akibatnya banyak sekali produk ornamen di zaman sekarang ini yang hanya mementingkan nilai estetis tanpa menghiraukan makna yang sesungguhnya.

Oleh karena itu, pendokumentasian, pengkajian, pembelajaran hingga penyebarluasan tentang penelitian ornamen pepatran kertagosa ini perlu dilakukan dengan pendekatan hermeunetik yang bersifat kualitatif, di mana penulis menyesuaikan dengan ruang lingkup wacana budaya masyarakat Bali.

\section{METODE PENELITIAN}

Pendekatan yang dipergunakan dalam penelitian ini adalah ilmu tafsir (hermeunetik) ${ }^{4}$ atas persepsi ornamen pepatraan pada meja dan kursi di ruang pengadilan Kertha Gosa Klungkung Bali. Oleh karena itu, langkah penting dalam hermeunetik tidak lain adalah suatu tafsir. Menafsirkan berarti mengungkapkan apa yang dianggap sebagai hal-hal yang diacu oleh sebuah teks. Penelitian ini bersifat deskriptif dalam bentuk kualitatif. Waktu yang dilakukan selama satu minggu berada di Klungkung Bali pada bulan Januari 2017. Langkah-langkah yang dilakukan yaitu dengan teknik pengumpulan data berupa observasi lapangan secara langsung di Kompleks Taman Gili Klungkung (Kertagosa), studi pustaka berupa buku-buku tentang ornamen Bali dan Kerajaan Klungkung yang sudah tersebar di daerah lokal, serta komunikasi langsung dalam bentuk wawancara.

\section{HASIL DAN PEMBAHASAN}

\section{Ornamen pepatraan}

Pepatraan merupakan stilasi dari tumbuhan dan diubah menjadi bentuk yang mempunyai nilai estetis. Tumbuhan yang distilasi dapat berupa daun-daunan, bunga atau kombinasi di antaranya. Pepatran sendiri berasal dari bahasa sansekerta, patra yang berarti daun (Purwadi, Priyo Purnomo Eko, 2005).

Ornamen pepatraan adalah ornamen yang ide atau konsep di ambil dari tamanan yang merambat, seperti: tanaman labu, pare, timun, dan tanaman merambat liar, yang biasanya numpang pada pohon-pohon besar sebagai pagar rumah serta aneka bunga sebagaimana yang akan dibahas di

\footnotetext{
${ }^{1}$ Kerta yang berarti hasil, kemakmuran .

${ }^{2}$ Gosa yang berarti diskusi/ tempat diskusi.

${ }^{3}$ Pepatraan berasal dari kata patra yang berarti daun.

${ }^{4}$ Menurut Joyce Marcella Laurens persepsi adalah interpretasi dari pengalaman yang mempunyai makna (2004:47). Artinya interpretasi (tafsir)untuk menghasilkan makna ialah dengan pendekatan hermeunetik.
} 
Klungkung Bali

sub bab selanjutnya. Tanaman ini oleh senimannya dideformasi atau distilir menjadi sebuah karya seni berupa pengulangan, baik secara melingkar, lurus dikenal dengan nama pepatran. Tujuan pepatran ini adalah untuk menghias rumah pribadi, adat, tempat suci yang khusus berkembang di Bali.

Pepatraan ini menghiasi bagian-bagian yang lebar dan memanjang, baik berupa segi empat, segi empat panjang, baik tempatnya di tengah, dipinggir/bidang bidang yang lebar, juga sebagai pelengkap dari ornament kekarangan.

Setiap patra memiliki identitas yang kuat untuk penampilannya sehingga mudah untuk diketahui. Pepatraan yang juga banyak didasarkan pada bentuk keindahan flora diwujudkan serta kemungkinan memungkinkan berasal dari negara asalnya yang merupakan jenis perwujudannya. Dalam penerapannya dapat bervariasi sesuai kreasi masing-masing seniman Sangging yang merancang tanpa meninggalkan pakem-pakem identitasnya (Arsitektur Tradisional Daerah Bali, 1981/1982).

Makna yang terkandung pada pepatraan adalah memberikan perlindungan kepada kehidupan manusia dari rasa takut, panas, haus dan yang lainnya. Sehingga memberikan kenyamanan bagi manusia yang tinggal dilingkungan bangunan yang dihiasi oleh pepatraan.

\section{Ornamen pepatraan pada meja dan kursi di kertagosa bali Ketha gosa}

Seperti yang sudah dipaparkan dalam pendahuluan, dalam sub bab kedua ini penulis akan membahas inti dari permasalahan yang akan dikaji. Penempatan dan penggunaan ragam hias yang disesuaikan dengan maksud serta tujuannya, akan mempengaruhi pembawaan falsafah berkehidupan, menurut kepercayaan tradisi adat istiadat masyarakat lokal Bali.

Kertha Gosa yang berarti tempat pembahasan segala sesuatu yang bertalian dengan situasi keamanan, kemakmuran serta keadilan wilayah kerajaan Bali, juga pernah difungsikan sebagai balai sidang pengadilan selama berlangsungnya birokrasi kolonial Belanda di Klungkung (19081942), dan sejak diangkatnya pejabat pribumi menjadi kepala daerah kerajaan di Klungkung (Ida I Dewa Agung Negara Klungkung) pada tahun 1929. Menurut Candra Sengkala yang terpahat di Pemedal Agung (Pintu Utama) Puri, Kertha Gosa sudah ada pada tahun Caka Cakra Yuyu Paksi-Paksi, yang masing-masing bernilai 1.6,2.2 (I Gusti Made Warsika, 1986). Dst. Jadi tahun 1622 atau tahun 1700 Masehi ketika I Dewa Agung Jambe sedang memerintah Klungkung (I Gusti Made Warsika, 1986). Dst.

Setiap tahun sekali tiap-tiap hari Purnamaning Kapat Balai Kertha Gosa ini adalah sebagai tempat sidangnya para raja bawahan diseluruh Bali. Tugas susuhan tertinggi yaitu memberikan pengarahan serta keputusan-keputusan berdasarkan kondisi dan kebutuhan. Setiap harinya balai ini digunakan sebagai tempat ngaturang pemijan (bersantap) bagi para begawanta (pendeta istana) dan para pendeta lainnya, juga sebagai balai penerima tamu dari negara asing, seperti Belanda, Inggris, Portugis, dan Cina bila ingin bertemu dengan Susuhanan.

Pada Balai ini terdapat sebuah meja berukir warna emas dan merah, enam buah kursi dengan didominasi oleh ornamen pepatraan pada bagian sandaran kursi , kaki kursi serta kaki meja sidang.

\footnotetext{
${ }^{5}$ Candra Sengkala adalah suatu cara penulisan tahun, bulan dan hari dengan gambar-gambar binatang, tumbuhtumbuhan, anggota badan manusia, serta isi alam raya yang mempunyai arti dan nilai tertentu.
} 


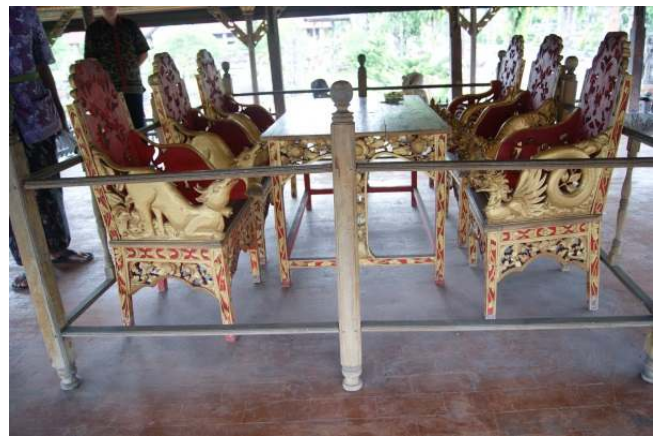

Gambar 1. Balai Kertha Gosa yang dilengkapi oleh satu meja dan enam buah kursi. Dokumentasi pribadi oleh An-nisaa Kurnia, 2017.

\section{Analisis kursi dan meja kertha gosa}

Pada sub bab sebelumnya telah diperlihatkan susunan letak kursi dan meja yang saling berhadapan. Secara keseluruhan bentuk dan komposisi warna sama. Namun, dalam sub bab ini penulis akan menganalisis bentuk ukiran pepatraan tersebut yang terdapat dalam kursi dan meja.

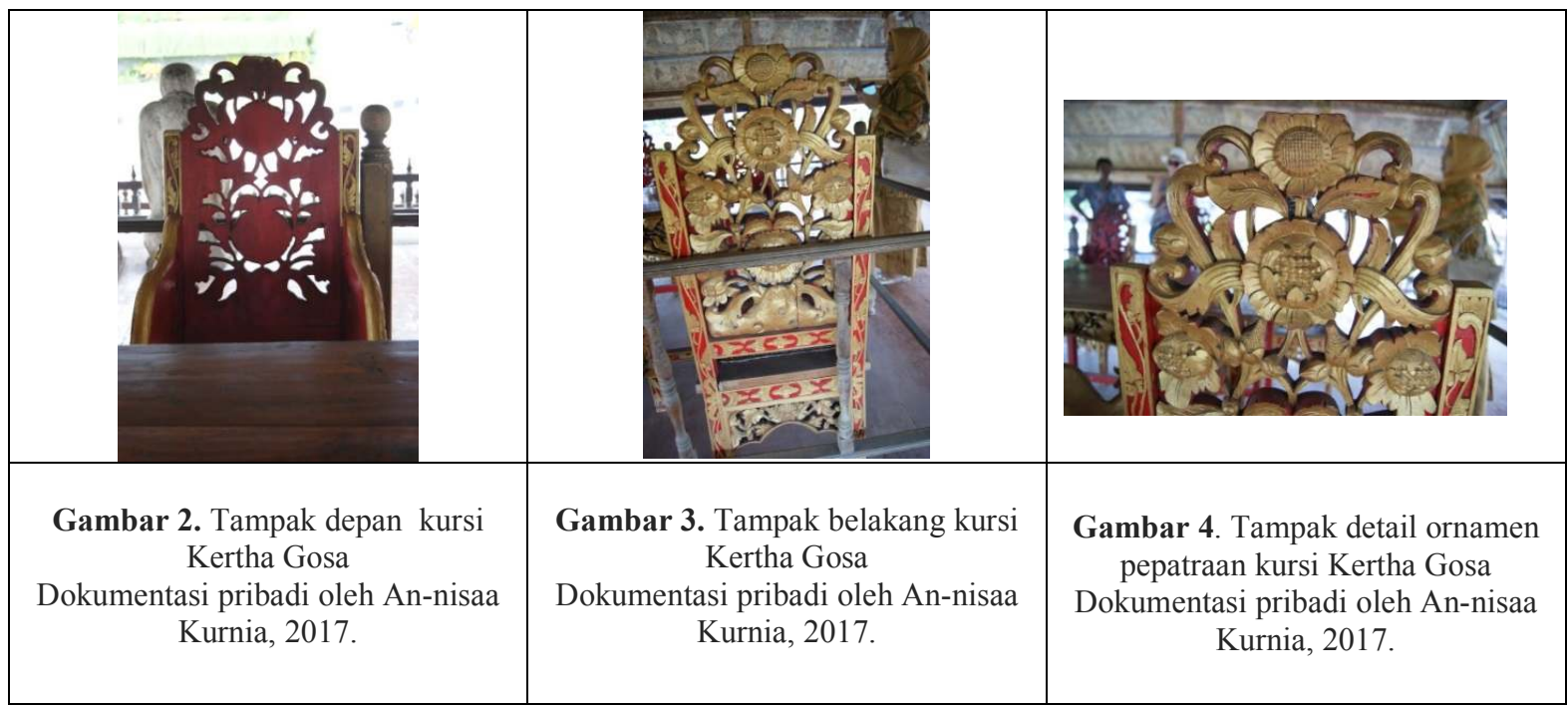

Pada gambar 4 bisa terlihat detail ornamen pepatraan dari tampak belakang kursi. Namun penulis menggambarkan kembali detail ornamen pepatraan tersebut. Dalam tahapan ini penulis menemukan asal sumber jenis flora yang digunakan untuk sandaran kursi tersebut. Ini merupakan bunga seruni ${ }^{6}$ yang mengalami proses stilasi.

Gambaran ulang oleh penulis. Dihasilkan bahwa bunga yang terletak paling atas ialah stilasi bunga seruni, di bagian tengah merupakan seruni yang telah melewati proses stilasi kedua kalinya untuk menghasilkan suatu estetika bentuk ornamen yang tidak monoton dan di bagian paling bawah terdapat dua buah kuncup bunga seruni yang masih belum mekar. (Perhatikan skema berikut).

\footnotetext{
${ }^{6}$ Bunga Seruni, Krisan atau biasa disebut juga dengan Krisantemun
} 

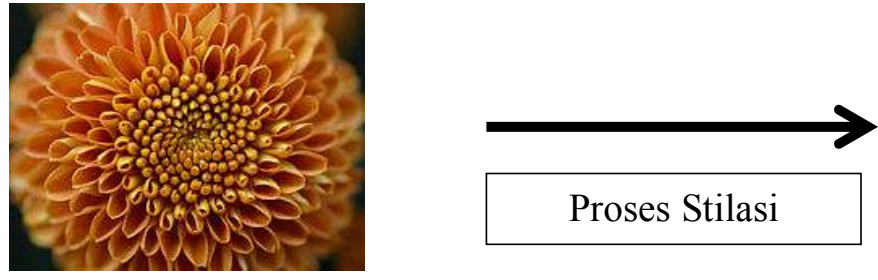

Gambar 5. Bunga Seruni

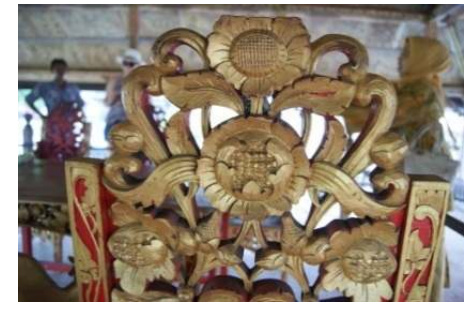

Hasil Stilasi bunga Seruni yang dipalikasikan pada kursi Kertha Gosa.

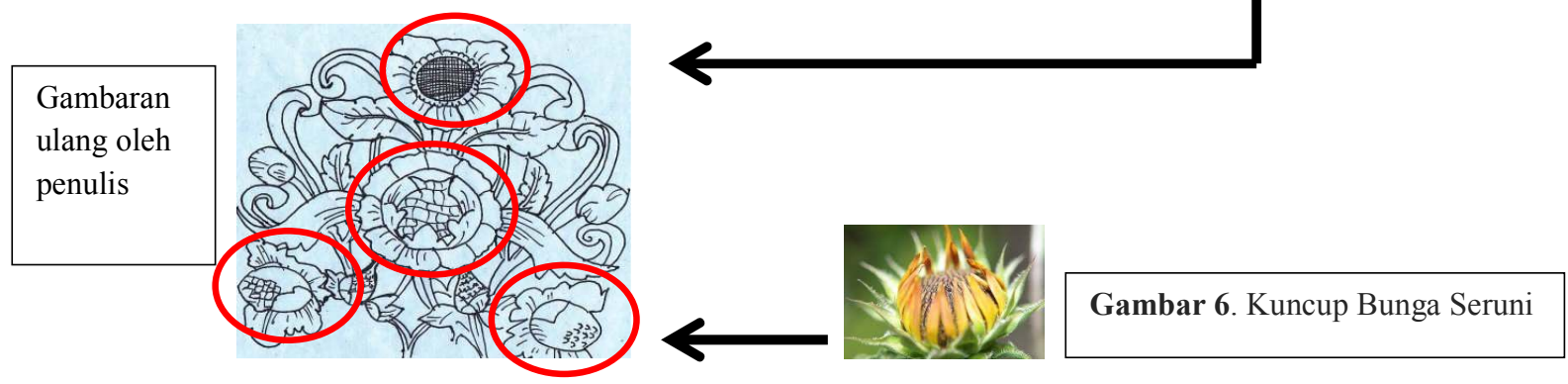

Ornamen patra (motif bunga) ini disebut seserunian yang merupakan motif asal Bali. Motif bunga ini digolongkan kembali ke dalam suatu patra berjenis patra Cina. Hasil analisis penulis menyebutkan bahwa ini adalah termasuk jenis patra Cina, karena dahulu Kerajaan Majapahit dipengaruhi oleh budaya Cina yang datang ke Bali sekitar taun 1400 Masehi.

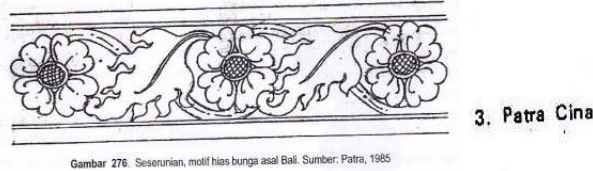

Gambar 7. Motif Bunga Seserunian Bali Sumber, Patra: 1985

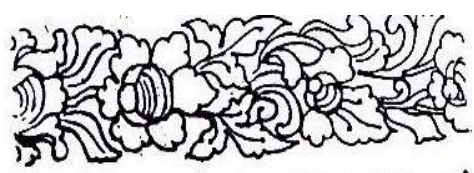

Gambar 8. Motif Bunga Seserunian Bâli Sumber, Ornamen Nusantara: 2009

Pada gambar 4 bisa terlihat bahwa hasil stilasi dari bentuk motif bunga tersebut ialah dari bunga seruni. Selain itu, terdapat pula bentuk sebuah lung dan sulur yang pembahasannya akan dibahas di bawah ini.

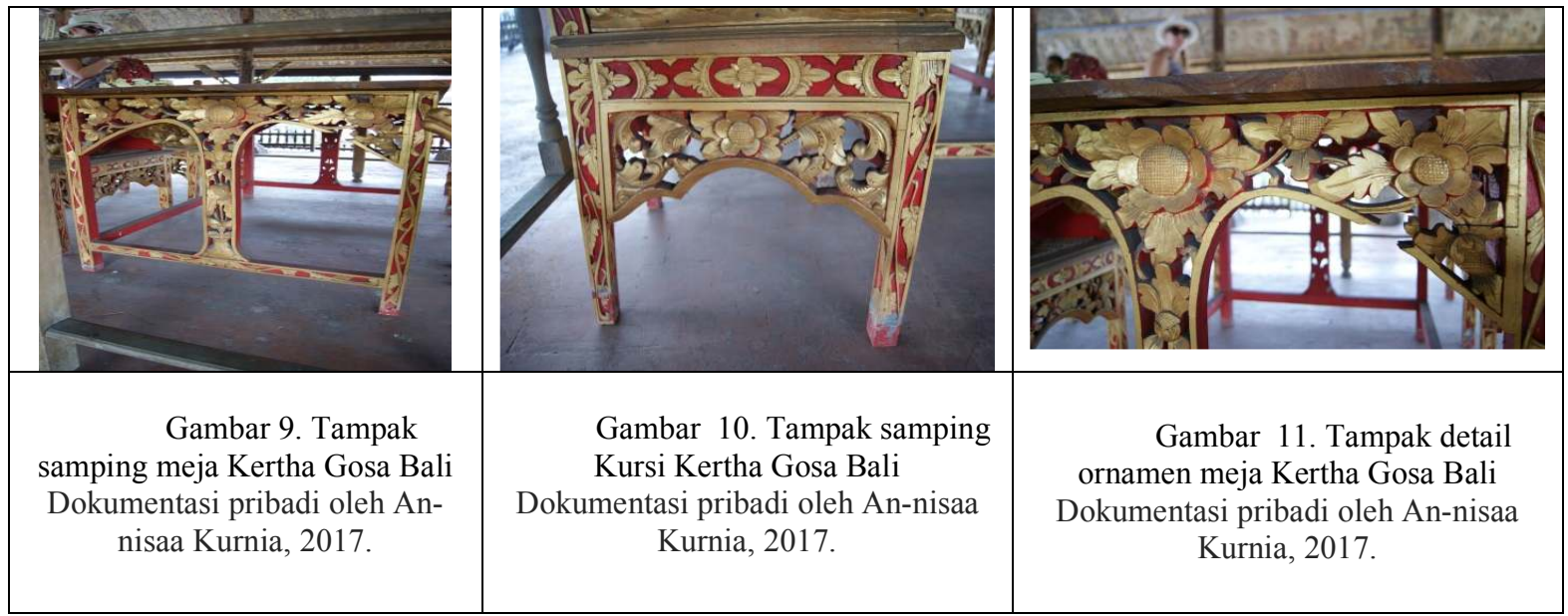


Kata lung dalam bahasa Jawa menunjuk pada sejenis tunas atau Batang tanaman menjalar yang masih muda dan melengkung-lengkung bentuknya (Aryo Sunaryo, 2009). Dst. Sementara sulur dipakai untuk menamakan motif hias tumbuh tumbuhan yang digubah dengan bentuk dasar lengkung pilin tegar dan juga bagian batang yang menjalar dan menyerupai spiral.

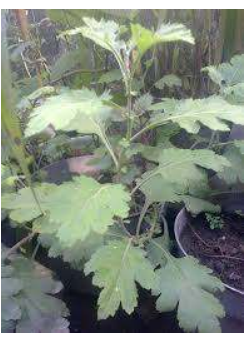

Gambar 12. Batang dan Daun Bunga Seruni

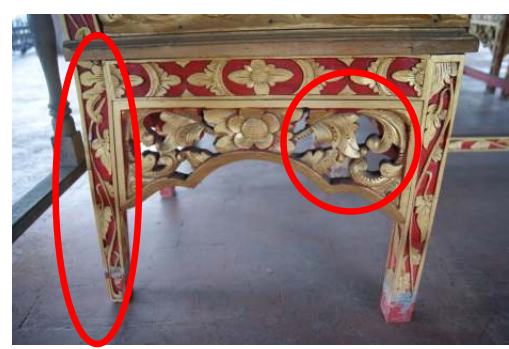

Hasil Stilasi batang dan daun bunga seruni

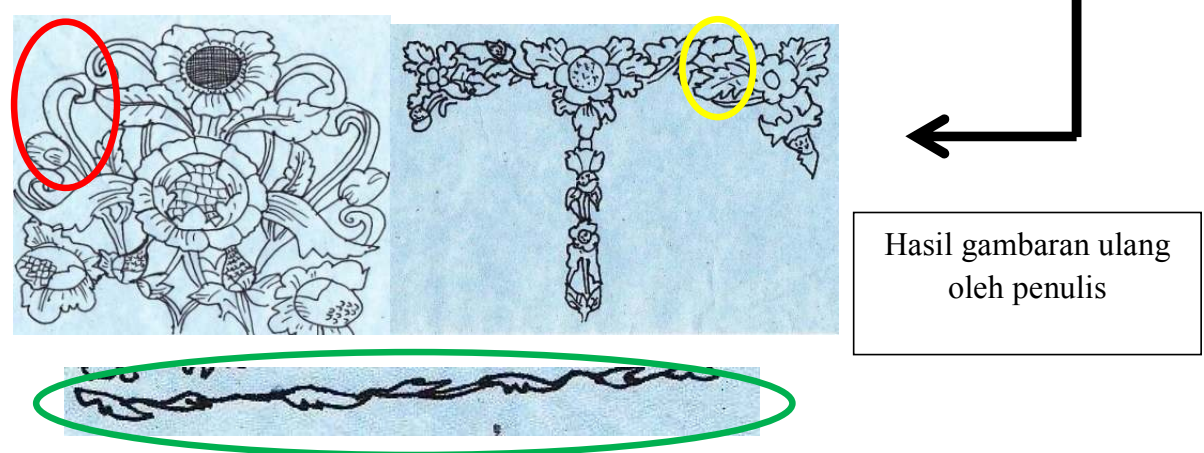

Keterangan :

-Warna Kuning : menunjukkan hasil stilasi dari daun bunga seruni yang digambarkan pada gambar 12

-Warna Merah : menunjukkan hasil stilasi dari batang bunga seruni yang digambarkan pada gambar 12 menghasilkan stilasi berbentuk lung.

-Warna hijau : menunjukka hasil stilasi dari daun dan batang bunga seruni yang digambarkan pada gambar 12 menghasilkan stilasi berbentuk sulur.

\section{Analisis pemaknaan ornamen kursi dan meja kertha gosa}

Dari sub bab sebelumnya telah dibuktikan bahwa ornamen pepatraan yang ada di kursi dan meja Kertha Gosa merupakan hasil stilasi dari tanaman bunga seruni. Bunga seruni ini diintroduksi dari daratanCina ke Jepang pada zaman nara,sedangkan di daratan Cina bunga Seruni ini sudah dibudidayakan sejak 3.000 tahun yang lalu. Di Cina dan Jepang bunga seruni ini adalah bunga langka dan mahal serta mempunyai nilai kehormatan dari bangsawan terhormat serta dijadikan lambang kekaisaran.

Dalam agama Hindu,seperti yang diungkapkan oleh Muhammad Doddy AB \& Sriyanto (2011) terdapat sistem kasta yang berfungsi sebagai penanda struktur sosial atau tingkatan sosial seseorang yang terdiri dari :

\section{Brahmana : pendeta}

2. Ksatria : raja, bangsawan, prajurit

3. Waisya : petani, pedagang, pengrajin, peternak

4. Sudra : pekerja kasar dan budak 
Dalam analisis ini bisa dibuktikan bahwa akibat dari adanya akulturasi antara budaya Cina yang mempengaruhi Majapahit di Bali membawa pengaruh sampai kepada sistem pemerintahannya yang terdapat di Kerajaan Klungkung Kertha Gosa Bali. Bunga seruni ini digunakan di kursi dan meja seorang raja (hakim), pendeta ,dan prajurit (juru tulis). Terbukti bahwa bunga seruni ini di Bali menandakan bahwa penggunanya atau subjeknya digunakan oleh para Brahmana dan Ksatria.Sama halnya dengan di Cina dan Jepang yang menggunakan bunga seruni ini adalah lambang dari suatu kehormatan, kewibawaan, keagungan seorang bangsawan.

Pembahasan analisis penelitian ini pun membuktikan adanya keterkaitan warna yang diaplikasikan pada meja dan kursi Kertha Gosa Bali yaitu merah dan kuning emas . Arti warna yang digunakan dalam semboyan Bali, antara lain:

1. Warna dasar biru tua mengandung arti toleransi;

2. Warna kuning emas mengandung arti luhur atau agung;

3. Warna merah mengandung arti keperwiraan;

4. Warna putih mengandung arti suci.

Dari seluruh hasil pembahasan dapat dibuktikan bahwa dalam penggunaan warna juga membawa makna yang secara simbolis mewakili sistem dalam suatu pengadilan (Kertha Gosa). Warna merah yang diaplikasikan pada meja dan kursi mengandung arti keperwiraaan,bagaimana seorang raja (hakim) dapat mengadili suatu perkara dengan pembawaan wibawa yang tegas dalam mengambil keputusan, sedangkan warna kuning emas membawa suatu pemaknaan yang luhur atau agung, karena seorang pemimpin (raja atau pengadil) biasanya di zaman sekarang ini pun seorang hakim diutus dengan sebutan yang mulia $^{7}$ yang berarti seseorang yang diagungkan, diluhurkan, dihormati, sama halnya seperti seorang raja (pengadil/hakim) di Kertha Gosa.

\section{KESIMPULAN}

Kehadiran sebuah ornamen tidak semata sebagai pengisi ruang kosong dan tanpa arti, terlebih untuk karya, peninggalan masa lalu seperti meja dan kursi di Kertha Gosa Bali. Bentuk-bentuk ornamen tersebut berasal dari bentuk tumbuhan termasuk bunga yang digolongkan ke dalam jenis pepatraan di Bali. Bentuk tersebut lalu distilasi menyerupai bentuk aslinya yang banyak dipengaruhi oleh bentuk ikal (lung) dan menjalar (sulur). Pada bangunan-bangunan tradisional, ornamen banyak sekali ditemukan, apalagi pada bangunan pengadilan pada zaman kerajaan, dan tentunya mempunyai hakekat tersendiri bagi penggunanya diiringi dengan budaya, adat istiadat, agama Bali yang masih membudaya bahkan sampai dengan saat ini. Ornamen dalam bangunan tradisional mengandung arti dan maksud tertentu. Fungsi utamanya yaitu penyajian suatu keindahan dalam suatu seni ukir, Bali memang pusatnya, kedua ornamen pepatraan tersebut digunakan untuk ungkapan simbolis seperti hasil stilasi dari bunga seruni yang melambangkan kehormatan, kewibawaan, keagungan kaum bangsawan (di Bali termasuk Brahmana dan Ksatria) dan warna yang diaplikasikan merupakan warna yang pada dasarnya mempunyai makna seperti merah menandakan keperwiraan dan kuning emas menandakan keagungan, ketiga ialah sebagai alat komunikasi sebagai suatu informasi oleh ornamen yang digunakan. Seluruhnya bisa dicapai dengan dasar estetika, etika dan logika dalam berkehidupan.

\section{UCAPAN TERIMA KASIH}

Dengan terselesaikannya Karya Ilmiah ini, penulis mengucapkan terimakasih kepada:

1. Dosen pembimbing saya bapak Anung Bambang Studyanto, bapak Rahmanu Widayat dan bapak Setyawanyang telah membantu untuk penyusunan karya ilmah saya.

\footnotetext{
${ }^{7}$ Yang Mulia, panggilan untuk seorang Hakim menurut tata tertib persidangan,sedangkan dasar hukumnya terdapat dalam peratutan Mahkamah Konstitusi No.19 tahun 2009 tentang tata tertib persidangan.
} 
2. Dinas Kepariwisataan Klungkung (Semarapura) Bali.

3. Bapak Ida Dalem Smara Putra sebagai penerus Raja Klungkung ke 21.

4. Pelukis Maestro Kamasan Bali bapak I Nyoman Mandra.

\section{REFERENSI}

Gde Suardana I Nyoman (2015). Rupa nir-rupa arsitektur Bali. Bali: Buku Arti

Made Warsika I Gusti (1986). Kertha Gosa selayang pandang. Klungkung Bali: Dinas Kepariwisataan.

Mangunwijaya Y.B. (2013). Wastu Citra. Jakarta: Gramedia Pustaka Utama.

Muhammad Doddy AB \& Sriyanto (2011). Menguasai IPS Sistem Kebut Semalam. Jakarta: Pustaka Gema Media.

Purwadi ,dkk. (2005). Kamus Sansekerta Indonesia. Yogyakarta: Budaya Jawa.

Sajidan (2012). Pedoman Penulisan Skripsi, Fakultas Keguruan dan Ilmu Pendidikan Universitas Sebelas Maret Surakarta.

Soepratno, BA. (1983). Ornamen Ukir Kayu Tradisional Jawa jilid 1.Semarang: EFFHAR

Sunaryo,Aryo (2009).Ornamen Nusantara. Semarang: Dahara Prize

Grace Hartanti \& Amarena Nediari (April 2014). Pendokumentasian aplikasi ragam hias budaya bali sebagai upaya konservasi budaya bangsa khususnya pada perancangan interior. Jurnal Humaniora, 5(1), 521-540.

Rahmanu Widayat \& Anung B. Studyanto (2011, September). Berhentinya membangun tradisi rumah Jawa. Jurnal Etnografi, 11 (2), 10-19. 